\title{
Surface Accessibility with Spatial Analysis During Fire Extinguishing Procedures: Example on the Island of Vis
}

\author{
Kruno Lepoglavec ${ }^{1 *}$, Josip Žaček ${ }^{2}$, Hrvoje Nevečerel ${ }^{1}$, Ante Seletković ${ }^{3}$, Zdravko Pandur $^{1}$, Marin Bačić ${ }^{1}$
}

(1) University of Zagreb, Faculty of Forestry, Department of Forest Engineering, Svetošimunska 25, HR-10000 Zagreb, Croatia; (2) Nova Jošava 34, HR-33515 Orahovica, Croatia; (3) University of Zagreb, Faculty of Forestry, Department of Forest Inventory and Management, Svetošimunska 25, HR-10000 Zagreb, Croatia

* Correspondence: e-mail: lepoglavec@sumfak.hr
Citation: LEPOGLAVEC K, ŽAČEK J, NEVEČEREL H, SELETKOVIĆ A, PANDUR Z, BAČIĆ M 2017 Surface Accessibility with Spatial Analysis During Fire Extinguishing Procedures: Example on the Island of Vis. South-east Eur for 8 (2): 107-115. DOI: https://doi.org/10.15177/seefor.17-15

Received: 06 Sep 2016; Revised: 20 Nov 2017; Accepted: 23 Nov 2017; Published online: 4 Dec 2017

\begin{abstract}
Background and Purpose: The existing public and forest transport infrastructure (truck forest roads) are permanent objects used when passing through forests. They also serve as a firefighter belt and provide direct access to firefighting vehicles, or are used as the starting point where firefighting teams extinguish fires or move toward remote fires. The paper identifies the existing fire road network (including public roads, forest roads, non-classified roads and fire roads) for access of firefighting vehicles during fire extinguishing interventions.

Material and Methods: An analysis of the intervention rate was conducted on a dispersive sample ( 35 positions) from two volunteer fire associations (VFA) on the island of Vis. Also, an analysis of the surface availability to fire vehicles concerning the time of departure from the fire station was conducted, as well as the comparison with the Standard time of intervention defined by the regulations on fire department organization in the Republic of Croatia.

Results: For each simulated fire location for intervention of two existing volunteer fire associations: VFA Komiža and VFA Vis, results show that for a few fire locations, despite a smaller distance from the VFA Komiža, a quicker intervention is possible from the VFA Vis (locations 4, 5 and 14), and vice versa (locations 21, 22 and 25). With the use of a New Service Area, tool intervention times regarding different areas were calculated. Intervention times were divided into intervals: $<5$ $\mathrm{min}, 5-10 \mathrm{~min}, 10-15 \mathrm{~min}, 15-25 \mathrm{~min}$ and >25 min. The last two categories of area are beyond reach for firefighters within the Standard time of intervention ( $15 \mathrm{~min}$ ) and together they comprise to $27.88 \%$ of the total research area.

Conclusions: The results of Closest Facility tool indicate that for the simulated fire position the best/fastest route is not always the shortest one, because of a significant effect of the structural elements of each road, the state of the road and the longitudinal slope of the road itself. One of the possible approaches to gain access to the area for fire-fighting, as well as to prioritize fire roads regarding maintenance/reconstruction is to improve road conditions, and thus increase the average driving speed.
\end{abstract}

Keywords: fire road infrastructure, fires, access time, GIS analysis

\section{INTRODUCTION}

A forest fire is uncontrollable, destructive movement of fire on the forest surface. It is categorized as a natural disaster and distinguished by type, origin and resulting damage. There are specific needs regarding temperature, pressure and oxygen required for fire, and if one of them is removed, the fire will stop [1]. Forest fires represent a great danger to the forests and forest land in the Republic of Croatia, and are common to the climate in which we live, especially in Dalmatia, Istria, on islands and in Dalmatian Hinterland.

Recently, the danger of forest fires has become extremely high, mostly due to the extensive climate change (long hot summers, warm autumns, strong winds, and long periods with very high temperatures). In Istria and the Croatian Littoral, about $70 \%$ of fires emerge in February, March and April, while 
in Dalmatia most fires occur in July and August. In Croatia, the monitoring and processing of data related to forest fires began in 1955. According to these data, a total of 10,369 fires, or an average of 370 forest fires per year [2] occurred in the period from 1955 to 1984 . In the period from 1995 to 2014 in the Republic of Croatia, there were a total of 5,377 fires in forests and other land, and a total of 259,003.17 ha were under fire. In the mentioned twenty-year period, the annual average was 269 fires, with an average annual fire area of 12,950.16 ha [3]. The year 2007 was a record year when 706 forest fires were registered, causing damage to $68,171.00$ hectares.

The number of fires in the first half of the year 2017 (or until 15 July) was three times higher than in the year 2016. In the seven coastal counties, there were a total of 642 fires, while in the whole 2016 there were 214 [4]. This area covers $67,397.00$ ha.

When we talk about the causes of fires, only about $10 \%$ of fires have a known cause, a thunder stroke, while $90 \%$ of all fires are a result of accidental or deliberate human action (neglect, burning of agricultural waste, intentional fire, traffic, electricity lines, mines and other) [3]. The emergence of fires in the Dalmatian area is high due to the vegetation cover which consists of coniferous and broadleaved forests, pastures and agricultural land, and due to the neglect of people during agricultural work, soil cleansing and weeding of weeds [5]. A research by Netolicki et al. [6] has shown that the anthropogenic influence is considered to be the major factor in the outbreak of fires. High influence also lies in terrain morphology, geological substrate and soil. As Rosavec [7] points out, the higher probability of fires and the amount of burned surface can be determined by the condition of the vegetation and the climate. Martinović [8] points out that in the USA the most considerable damage is caused by forest fires, similar to those in our karst forest ecosystems, and points to the fact that attention should be paid to the pedological conditions of forest fires.

There are two groups of fire protection measures, both preventive and curative. Preventive measures are used to prevent or reduce the possibility of fires, while curative include the process of extinguishing and repairing the burnt area. Exceptional measures of both preventive and curative protection are fire roads. During fires, fire roads serve as a firefighting belt, provide access to firefighting vehicles, emergency vehicles and vehicles for the transportation of personnel and equipment, and can also serve as a place for firefighters to wait for the future fires, as well as places for pre-fire and anti-fire ignitions [9].

In this paper, the analyses are based on the use of firefighting vehicles for firefighting interventions, and the term "intervention" is considered as a movement of a fully qualified vehicle and equipment until the vehicle reaches the endpoint of the fire road. Of course, the intervention can be considered to consist of unified operations from the call itself up to access and shutdown or localisation of the fire.

Since time is the most important factor for reaching a fire, every efficient firefighting system, due to its rapid localisation, requires well-planned intervention, an appropriate risk assessment and management system, comprehensive training, and quick implementation of the above-mentioned steps through an application. Technology with a growing frequency of use in optimising this system is the Geographic Information System (GIS) [10-12]. Every day firefighters are faced with ever-increasing demands for work, so they have been forced to implement state-of-the-art tools, techniques and methods [13]. The imperative of all firefighting interventions is the speed and accuracy of the reaction. In this context, using GIS technologies enables us, thanks to implemented algorithms, to eliminate possible human errors when selecting a route, thus significantly shortening the time of intervention [13]. The most common data layers used by fire departments are streets, parcels, hydrants, public networks, rivers and lakes, business buildings, police and fire stations, schools and hospitals, satellite imagery and previous fire locations $[11,14]$.

\section{MATERIAL AND METHODS}

The main tool for conducting the analysis is the Network Analyst. It is a powerful ArcGIS extension and enables analysis based on topologically accurate traffic data [13]. It is useful in firefighting because it enables: to define the fire department closest to the fire area, estimate the travel time, select a new potential location, find the fastest route, nearest fire station, or define the optimal deployment of the existing fire departments. Three components are important when selecting a faster firefighting intervention: the location of the fire, the location of the fire department and the distance from the unit to the fire location.

The establishing of the database relies on the existing digitalized network of roads and on adding newly established traffic infrastructure (Figure 1), in which all "controversial" road segments are corrected directly on the field and recorded using GPSMAP 62S GPS, brand Garmin. In this paper cartographic background was used which was made in the transverse Mercator projection and by the reference coordinate system HTRS96 (Croatian Terrestrial Coordinate System at epoch 1995.55).

The control time of vehicle arrival at the test sites, i.e. the average travel time of the fire truck on particular road segments, and the trace recording were done by a GPS device mounted on the Mercedes Atego 1528 fire truck. This resulted in average speeds of the vehicle in all the routes used in the analyses, shown in different colours for a certain average driving speed (Figure 2). By calculating the length of each road segment and the required transition time, all the parameters necessary for calculating the fastest possible path to simulated fire positions can be obtained.

Based on such structured data layer, an analysis in Network Analyst can begin. With the aid of this tool, the fastest/closest firefighter unit to the fire position (on a dispersive sample) is defined. The tool also finds the fastest route and estimates the travel time to the site of intervention. Within Network

\footnotetext{
1 - Dijkstra's algorithm was designed by Dutch computer scientist Edsger Dijkstra, born in Rotterdam in 1930. In addition to the algorithm for searching the shortest route, Dijsktra was entrusted with computer science and with various algorithms for resource allocation, as well as the implementation of multiple task-based operating systems. The algorithm works on weighted graphs that have only the positive weights on lines. Dijkstra's algorithm is defined as a group of algorithms having one initial node, which means that the algorithm for each node in the graph will find the shortest path relative to the parent node [16].
} 


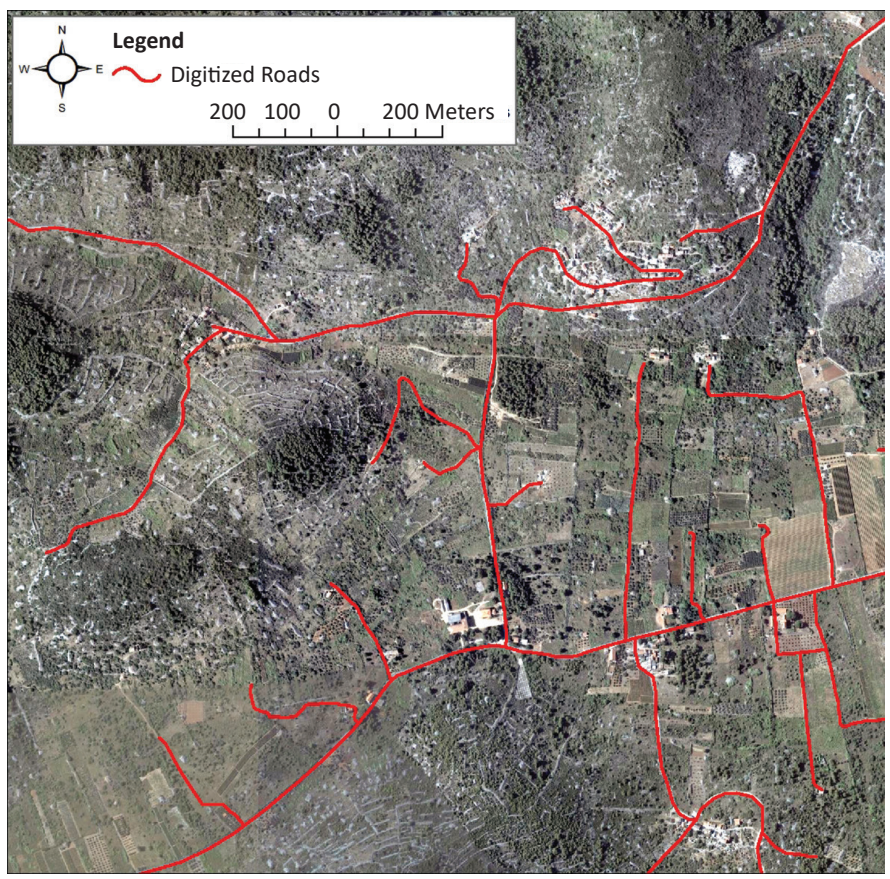

FIGURE 1. The method of digitizing a network of trafficable roads on digital orthophoto (DOP).

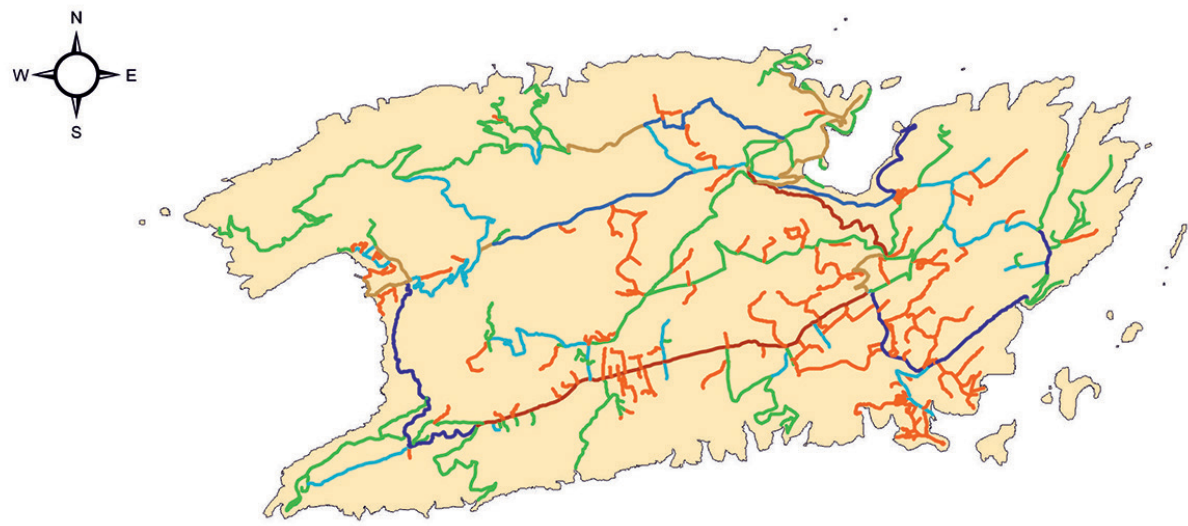

Legend



Roads (asphalt+macadam)

Average driving speed

$\sim 20 \mathrm{~km} / \mathrm{h} \sim 60 \mathrm{~km} / \mathrm{h}$

$\frown 40 \mathrm{~km} / \mathrm{h} \frown 90 \mathrm{~km} / \mathrm{h}$

$\frown 50 \mathrm{~km} / \mathrm{h}$



FIGURE 2. Transport infrastructure network with average driving speed. 
Analyst tools, Closest Facility tool is used, which is based on Dijkstra's algorithm ${ }^{1}$ or shortest path algorithm. The algorithm breaks the network into nodes, and the routes that link them are visualised by the vector line data with the attribute values. Additionally, each line between two nodes has a related value (cost or distance) that needs to be overcome in order to reach the destination node or point [15]. An important factor when choosing a route is not only speed but also traffic conditions on the road network, which in this case are the average driving speeds on certain road segments.

The model created for this research within Network Analyst tools, a tool entitled New Service Area was used. This tool gives us an output polygon that shows the area of a given firefighting station's intervention period through time aspect and distance. Also, tools such as Select, Clip, Merge, and Erase have also been used to calculate the availability of different surface areas at a certain time.

The aim of the analysis is to identify the location that covers the largest area and that makes responding to fires in standard intervention time possible. Standard intervention time is defined as the standard time set by the regulations on fire department organization in the Republic of Croatia, in which Article 19 states: "The distribution of fire brigade units on the territory of the Republic of Croatia should be such that the arrival of the fire brigade to intervene to the furthest place of the protected area is set to a fifteen-minute limit.".

\section{Research Area}

Forest administration (FA) office Split is one of the 16 administrations included within the Croatian Forests Ltd company. This FA manages forests between the Pag Bridge and Prevlaka, on the territory of four counties: Zadar, Šibenik-Knin, Split-Dalmatia and Dubrovnik-Neretva. The total area covered by the FA is $563,804.38$ ha, which is also the largest area covered by one administration office. Out of the total forest areas covered by this management, $444,175.16$ ha are covered forest areas, $105,825.20$ ha are uncovered forest areas and $13,804.02$ ha are barren forest areas [17].

FA Split includes 986 islands, five nature parks and four national parks. In the coastal area, FA Split manages species

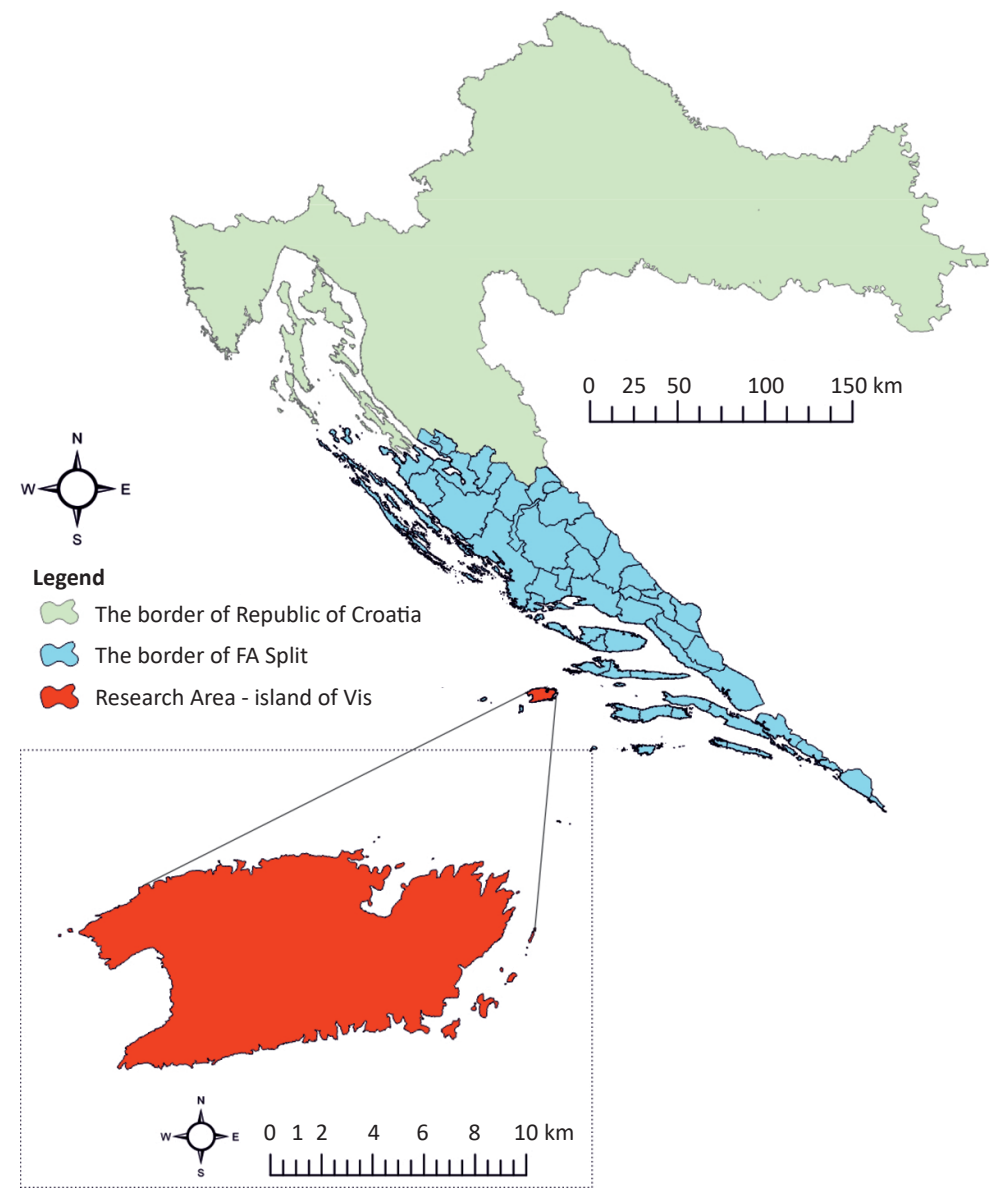

FIGURE 3. Research area - the island of Vis. 
preservation, forest protection, planting and other activities. With the rise of summer heat, the fear of possible upcoming fires grows, since fires are the greatest enemies of forest land. In the karst area, the greatest threat to forests are forests fires, so a lot of money is invested in the preventive protection of forests. Anti-fire prevention measures include the organisation of observatory firefighting service, the construction and maintenance of observation posts, the construction and maintenance of forest fire roads, the placing of warning signs and the preservation of forests. A big problem is that volunteer fire associations on the Adriatic islands and coastal areas have lately been in great trouble, quite often at the border of existence. The reason for this is primarily that a small number of young people are included in the associations, and that there is a growing lack of interest, insufficient equipment, obsolete equipment, and inability to acquire new equipment [5].

The island of Vis has been selected for research for a number of reasons, primarily due to the existence of two active voluntary firefighter associations, the existence of a large number of different road categories and their conditions (level of damage) with a total of $208.50 \mathrm{~km}$ in length, great distance of the island from the mainland (about $45 \mathrm{~km}$ ), and the fact that it is wholly unavailable for quick firefighting interventions from the air, so all fire protection and intervention depend on the existing roads.

The surface of the island is $90.3 \mathrm{~km}^{2}$, the total length of the indented and quite inaccessible coast is $77 \mathrm{~km}$. The island of Vis, according to the WGS84 geographic projection, is located between $16^{\circ} 02^{\prime} 22^{\prime \prime} \mathrm{E} 43^{\circ} 00^{\prime} 13^{\prime \prime} \mathrm{N}$ and $16^{\circ} 16^{\prime} 13^{\prime} \mathrm{E} 43^{\circ} 04^{\prime} 53^{\prime \prime} \mathrm{N}$.

\section{RESULTS}

The tools used in this research enabled us to create a supplemented road cadastre that was the input for all the necessary analysis foreseen in this research. The total length of roads that can be used in firefighting interventions is 208.50 kilometres, and the existing roads are divided into 552 segments of the researched road network with assigned average vehicle driving speeds. The road network designated for firefighting interventions is divided into segments defined by nodes (intersection points), i.e. intersections and road endings that according to the tool use and represent a mandatory intercept.

By simulation/random selection, 35 points have been set in the entire research area that represents areas of eventual fire (Figure 4). The points were determined by order of 1 to 35 , and a dispersed pattern was set. This analysis would point out that the closest route is not always the shortest one during the intervention due to different conditions of the roadway. The tool has proved to be efficient for making sensible objective decisions in the logistics of the fire extinguishing system.

To confirm a dispersive pattern of the simulated fires, a statistical analysis was carried out using the Average Network Neighbor tool. Given the value of Nearest Neighbor Ratio of 1.532692, a p-value of 0.000000 and a z-score of 6.028936 , there is a less than $1 \%$ likelihood that this dispersed pattern could be the result of random chance, proving the dispersed layout of the locations (Figure 5).

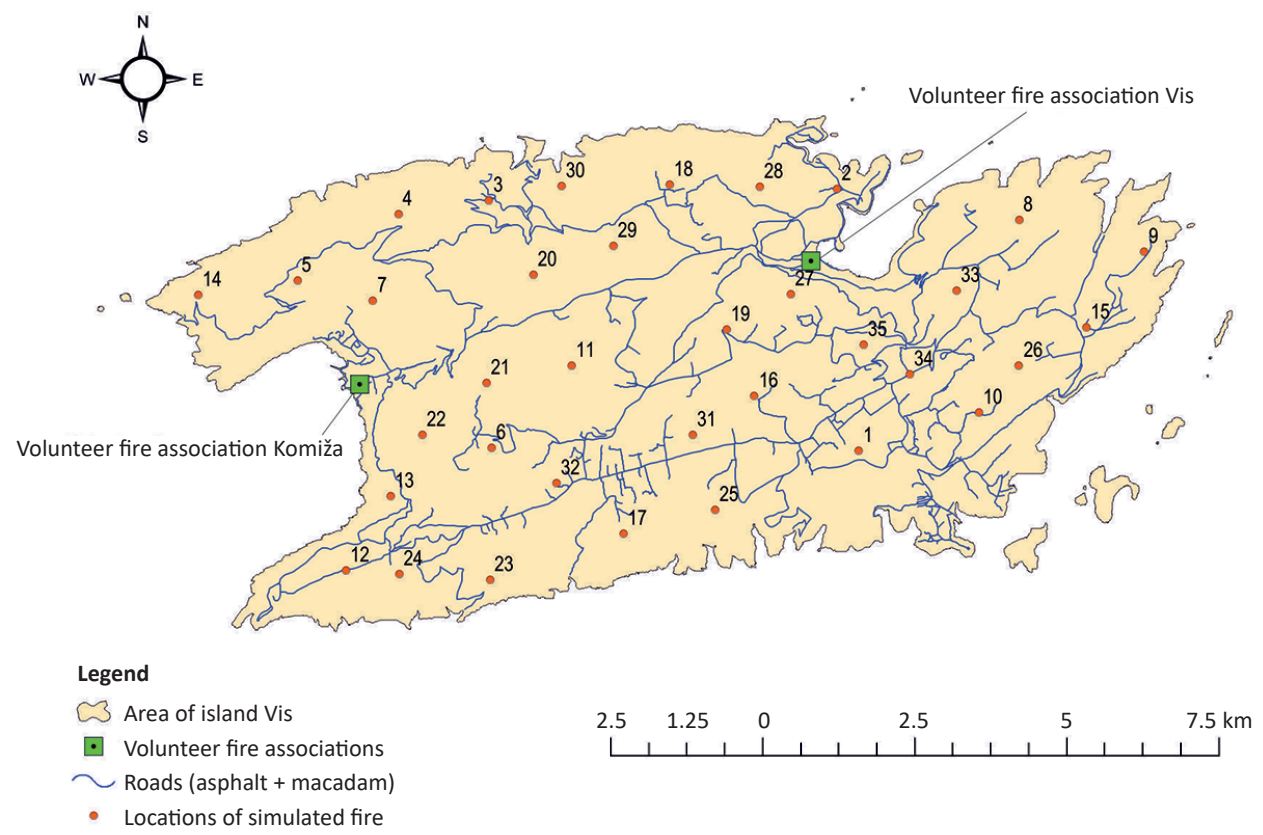

FIGURE 4. Spatial positions of simulated fires. 


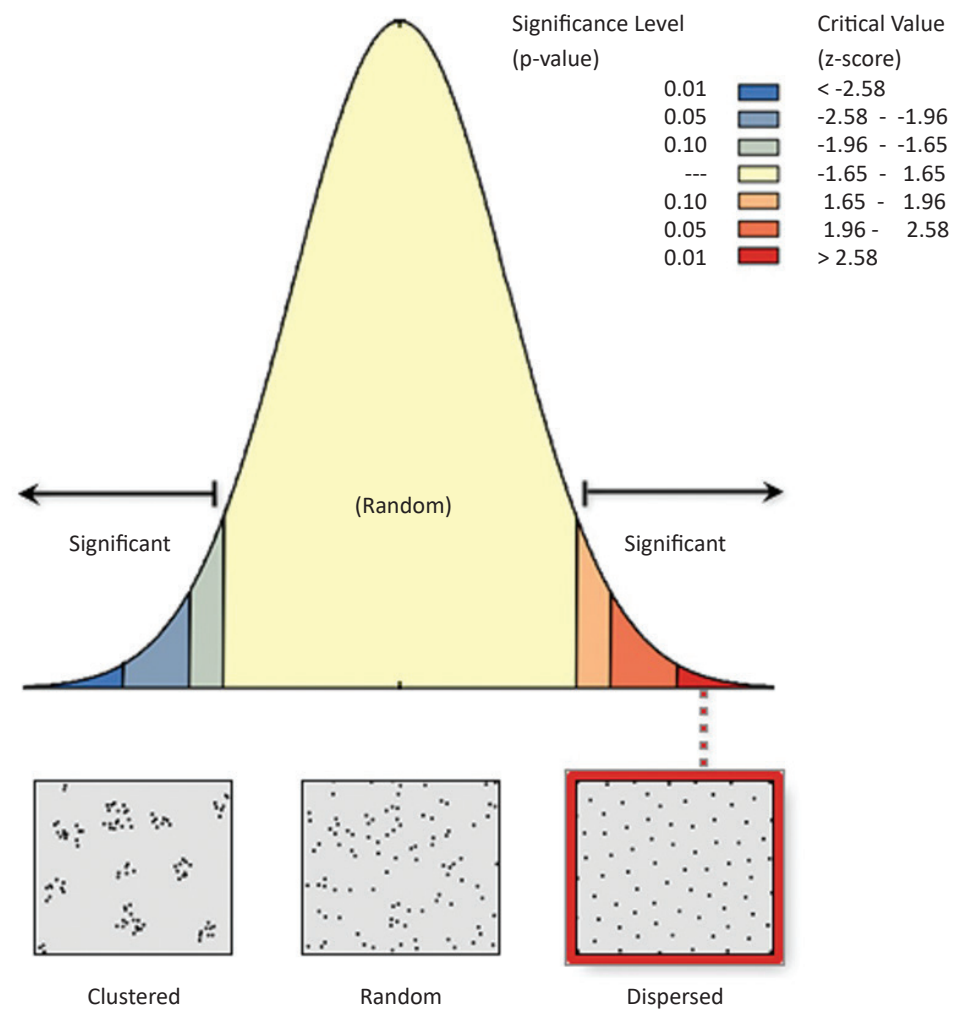

FIGURE 5. The results of testing the selected locations using the Average Network Neighbor tool.

For each simulated fire location, an analysis was conducted regarding the required time and length of the access route for intervention along with the two locations of existing volunteer fire associations: VFA Komiža and VFA Vis (Table 1). Time was displayed in minutes and distance in kilometres. The results show that for a few fire locations, despite a smaller distance from the VFA Komiža, a quicker intervention is possible from the VFA Vis (locations 4, 5 and 14), and vice versa (locations 21, 22 and 25). The reason for this is terrain configuration and the degree of road damages, which cause a decrease in the average driving speed of firefighter trucks on certain road segments, and therefore it takes longer for the firefighters to arrive at the intervention site.

With the use of a New Service Area, tool intervention times regarding different areas were calculated. Intervention times were divided into intervals: $<5 \mathrm{~min}, 5-10 \mathrm{~min}, 10-15 \mathrm{~min}$, 15-25 min and >25 min, so that it is possible to differentiate areas accessible within the standard time of 15 minutes. The last two categories (15-25 min and $>25 \mathrm{~min}$ ) shown in Figure 6 are beyond reach for firefighters within the standard time and together they comprise to $2,530.62$ ha which is $27.88 \%$ of the total research area.

Areas accessible at different time intervals were calculated for each of the volunteer fire associations separately to determine the area coverage of a particular firefighter unit.
The results show that areas accessible to firefighters within 5 minutes significantly differ between these two volunteer fire associations. The area accessible within 5 minutes to VFA Vis is twice the size of the area accessible to VFA Komiža in the given period.

This difference increases in favor of VFA Vis by increasing the time of intervention and within the standard time where almost $3 / 4$ of the areas' coverage/accessibility is in favor of VFA Vis, as opposed to the $1 / 4$ surface accessibility of VFA Komiža (Figure 7). It is also noticeable that after a time interval of 15 minutes, area coverage of VFA Vis enlarges, while of VFA Komiža it slightly decreases. Namely, during a time of intervention of more than 15 minutes, more rapid interventions are those of VFA Vis, regardless of the greater geometric distance in the case of VFA Komiža, all due to better linkage and driving speed from the direction of VFA Vis.

\section{DISCUSSION AND CONCLUSIONS}

The only efficient way to minimize damages caused by forest fires is the early detection of forest fires and fast and appropriate reaction, apart from applying preventive measures. Considerable efforts are therefore made to achieve early forest fire detection, which is traditionally 
TABLE 1. Intervention time and route distance for the simulated fire positions.

\begin{tabular}{|c|c|c|c|c|c|c|}
\hline \multirow{2}{*}{$\begin{array}{l}\text { Number of fire } \\
\text { intervention }\end{array}$} & \multicolumn{2}{|c|}{$\begin{array}{l}\text { Position of the location in WGS84 projection } \\
\text { (decimal degrees) }\end{array}$} & \multicolumn{2}{|c|}{ Volunteer fire association Vis } & \multicolumn{2}{|c|}{ Volunteer fire association Komiža } \\
\hline & $X$ coordinate & Y coordinate & $\begin{array}{l}\text { Total time } \\
\text { (min) }\end{array}$ & $\begin{array}{l}\text { Total length } \\
(\mathrm{km})\end{array}$ & $\begin{array}{l}\text { Total time } \\
(\mathrm{min})\end{array}$ & $\begin{array}{l}\text { Total length } \\
(\mathrm{km})\end{array}$ \\
\hline 1 & 16.19263726140 & 43.03225211140 & 12.55 & 10.67 & 14.15 & 13.14 \\
\hline 2 & 16.18816226600 & 43.07100964020 & 3.59 & 2.83 & 14.45 & 12.37 \\
\hline 3 & 16.11783006590 & 43.06902742350 & 9.75 & 8.05 & 16.12 & 12.89 \\
\hline 4 & 16.09959125940 & 43.06689427460 & 12.20 & 10.19 & 12.25 & 8.01 \\
\hline 5 & 16.07923187950 & 43.05708273680 & 16.89 & 12.53 & 16.93 & 10.35 \\
\hline 6 & 16.11864021660 & 43.03245320820 & 14.76 & 8.42 & 12.24 & 11.15 \\
\hline 7 & 16.09449014900 & 43.05408142500 & 13.01 & 11.04 & 2.74 & 1.98 \\
\hline 8 & 16.22491325090 & 43.06647735340 & 9.72 & 7.58 & 18.79 & 15.93 \\
\hline 9 & 16.25015627980 & 43.06177388930 & 15.46 & 11.04 & 23.94 & 22.75 \\
\hline 10 & 16.21694230240 & 43.03798073610 & 11.78 & 9.40 & 19.18 & 18.30 \\
\hline 11 & 16.13465577380 & 43.04468646290 & 9.86 & 5.62 & 13.66 & 8.57 \\
\hline 12 & 16.08933359600 & 43.01415857270 & 16.02 & 17.57 & 5.75 & 5.23 \\
\hline 13 & 16.09826107950 & 43.02517752550 & 13.61 & 12.26 & 3.14 & 3.04 \\
\hline 14 & 16.05923093460 & 43.05484236750 & 23.88 & 16.03 & 23.92 & 13.85 \\
\hline 15 & 16.23849347470 & 43.05062981980 & 12.06 & 9.34 & 20.53 & 21.04 \\
\hline 16 & 16.17159291420 & 43.04031236580 & 12.33 & 10.52 & 13.90 & 12.94 \\
\hline 17 & 16.14529954660 & 43.01985695470 & 13.36 & 13.68 & 9.88 & 9.37 \\
\hline 18 & 16.15433494290 & 43.07153270000 & 4.74 & 4.54 & 11.60 & 10.11 \\
\hline 19 & 16.16593334520 & 43.05008805760 & 10.99 & 8.03 & 15.77 & 12.32 \\
\hline 20 & 16.12691215820 & 43.05805362280 & 8.04 & 7.23 & 14.41 & 12.07 \\
\hline 21 & 16.11754499210 & 43.04201914320 & 17.12 & 9.74 & 14.61 & 12.47 \\
\hline 22 & 16.10457296290 & 43.03430003040 & 17.19 & 9.52 & 14.67 & 12.25 \\
\hline 23 & 16.11842325340 & 43.01285691380 & 19.64 & 18.40 & 12.45 & 9.15 \\
\hline 24 & 16.10005706530 & 43.01364699300 & 15.41 & 16.97 & 5.14 & 4.63 \\
\hline 25 & 16.16368732350 & 43.02340283510 & 12.38 & 11.44 & 12.31 & 11.69 \\
\hline 26 & 16.22496042720 & 43.04488603610 & 12.64 & 9.95 & 20.64 & 21.17 \\
\hline 27 & 16.17886306120 & 43.05534043610 & 1.89 & 1.71 & 10.95 & 10.06 \\
\hline 28 & 16.17249910410 & 43.07118406270 & 2.86 & 2.36 & 12.38 & 11.92 \\
\hline 29 & 16.14300495990 & 43.06239753250 & 5.24 & 5.39 & 11.61 & 10.24 \\
\hline 30 & 16.13248492740 & 43.07123310960 & 9.65 & 7.99 & 16.02 & 12.84 \\
\hline 31 & 16.15920936090 & 43.03447576190 & 10.16 & 11.09 & 9.13 & 10.06 \\
\hline 32 & 16.13171257660 & 43.02723197390 & 12.69 & 13.60 & 8.33 & 8.12 \\
\hline 33 & 16.21235163320 & 43.05594117490 & 7.72 & 6.45 & 16.79 & 14.80 \\
\hline 34 & 16.20291042160 & 43.04355160250 & 6.07 & 5.26 & 14.15 & 15.45 \\
\hline 35 & 16.19355270360 & 43.04787625460 & 7.30 & 6.04 & 16.37 & 14.39 \\
\hline
\end{tabular}

based on human surveillance [18]. Therefore, it is crucial to determine the optimum route that minimizes the travel time of the initial response team from fire headquarters to fire areas using firefighting trucks [19]. It is essential to pay close attention to a well-developed road network that allows access to fires on islands that are far off the mainland and where rapid air intervention is not possible, especially in the summer months when these areas have a high risk of fire due to long dry periods without rainfall and highly flammable plant species.
To maximize the existing traffic infrastructure for firefighting, it is important to determine the state of the road, its trafficability and the possible driving speed of firefighting vehicles. With the knowledge of all these details and GIS, it is possible to find the best and the fastest solution for individual firefighting interventions. Firefighting units have several GIS tools available for the analysis of intervention speed, which, as shown in this paper, can be categorised within the Network Analyst tools. It is also possible to conduct other analysis such as complex modelling of various hazard indexes, the 


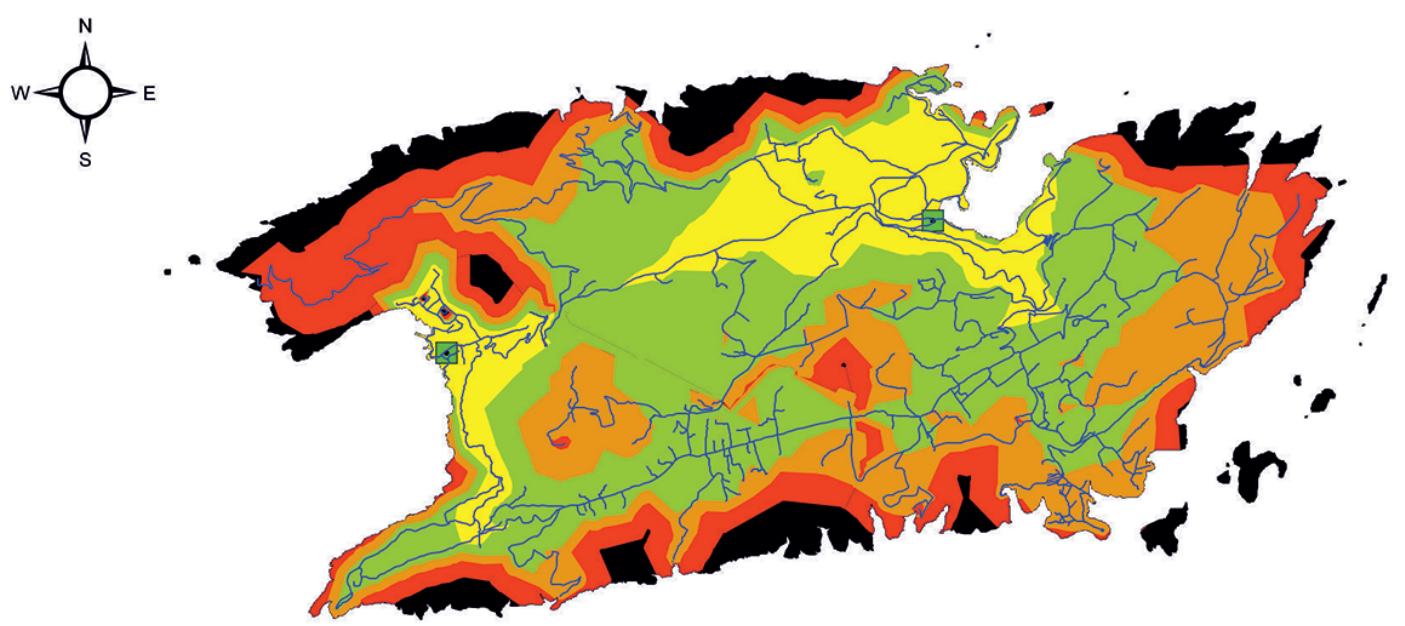

Legend

- Volunteer fire associations

$\frown$ Roads (asphalt + macadam)

Fire intervention time $(\mathrm{min})$
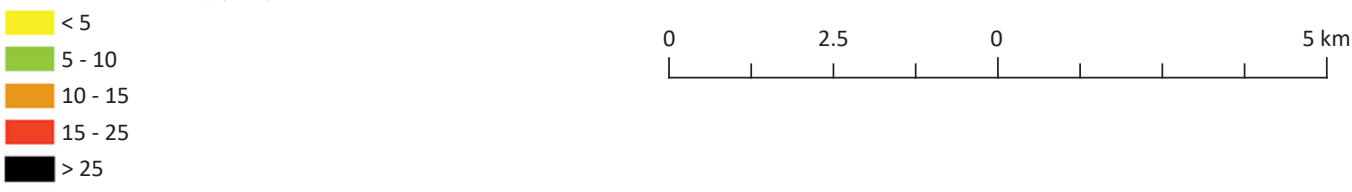

FIGURE 6. Firefighters' access within different time intervals.

degree of fire risk, fire susceptibility, topography and weather conditions, simpler visibility analysis, selection of optimal location of fire lookout towers and fire stations, determination of intervention location, etc. [13].

The results obtained with the Closest Facility tool indicate that for the simulated fire position the best/fastest route is not always the shortest one, because of a significant effect of the structural elements of each road, the state of the road and the longitudinal slope of the road itself. In addition to the variables used in this paper (average driving speed and road length), it is possible to define obstacles and constraints that block or hinder traffic on certain road segments [20]. For analysis of obstacles and changes in road conditions, it is necessary to carry out real-time analysis whereby the previously formed databases would obtain current road conditions, which would result in a change of intervention route [21, 22].

The New Service Area tool showed that approximately $1 / 4$ of the island's surface is unavailable to firefighters within a 15-minute standard time. The cartographic presentation gives us guidelines for reconstruction or maintenance of the existing roads, and thus a total increase in the average driving speed of firefighting vehicles would be possible. The areas shown in Figure 5 are a good indicator of areas where new roads need to be built to shorten the drive, all for comprehensive protection and possible interventions in the entire research area.

An important indicator of the conducted analysis is that much larger surface area is available to the VFA Vis within the standard time (Figure 7), because there are higher road categories in the vicinity of the city of Vis where the VFA is located, which then allows faster movement of firefighters due to improved traffic conditions and two traffic lanes.

The density of roads suitable for firefighting interventions is $23 \mathrm{~m} \cdot \mathrm{ha}^{-1}$. The established road density was shown to be insufficient, which prevents timely intervention on all the areas covered by this research. This is also contributed by the poor state of the upper rod layer on a large number of roads, which decreases the driving speed on both asphalt and macadam roads. One of the important problems identified is the position of volunteer fire associations located in the coastal part of the island in the centre of the cities of Vis and Komiža.

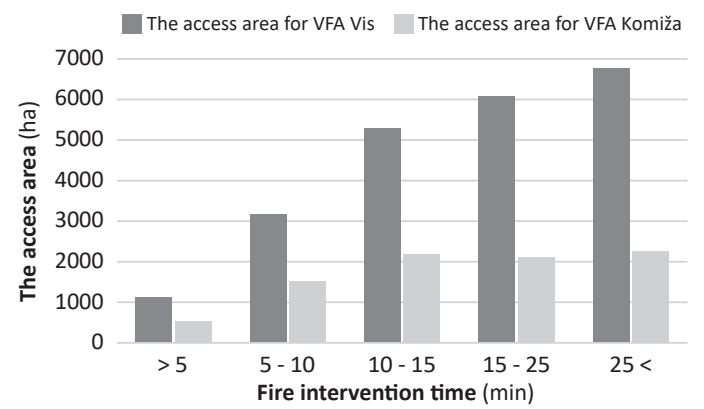

FIGURE 7. Firefighters' access within different time intervals for a particular volunteer fire association. 
They are not placed in ideal positions regarding road layout, terrain configuration and island indentation. This case shows the need to set up new firefighting stations or to seasonally displace them for better efficiency and better protection [23].

Taking into account all the given results in this paper, the time of intervention can be reduced by appropriate planning and realization of the proposed measures. The existing network of roads needs to be improved in qualitative and quantitative terms, and the available VFAs should be brought closer to possible interventions. This research has also shown the need to redefine the existing knowledge of the optimal density of roads in the island karst area because in the case of a fire the time of approach determines the success of the entire intervention system. It is not possible to propose a final solution by this research, but many questions arise that open the way for new research, oriented towards conscious and rational surface management where there is an obvious high risk of fire.

\section{REFERENCES}

1. PIČMAN D 2011 Interna skripta iz nastavnog predmeta Šumske protupožarne prometnice. University of Zagreb, Faculty of Forestry, Zagreb, Croatia, pp 1-63 (in Croatian)

2. ŽAČEK J 2017 Fire fighting infrastructure analysis of island Vis. Diploma thesis, University of Zagreb, Faculty of Forestry, Zagreb, Croatia, $42 \mathrm{p}$ (in Croatian)

3. BAKŠIĆ N, VUČETIĆ M, ŠPANJOL Ž 2015 A potential risk of fire on open space in the Republic of Croatia. Vatrogastvo $i$ upravljanje požarima (Fire fighting and management) 2: 3040 (in Croatian with English summary)

4. GOVERNMENT OF THE REPUBLIC OF CROATIA 2017 URL: https://vlada.gov.hr/vijesti/sjednica-vlade-broj-pozara-u2017-je-u-porastu-identificirat-cemo-preventivne-mjerekako-bismo-smanjili-rizike/22110 (2 August 2017)

5. NODILO J 2003 Fires on open spaces, islands and the littoral - an accident or a logical sequence of events? Šumarski list 127 (3-4): 171-176 (in Croatian with English summary)

6. NETOLICKI A, BLAŽEVIĆ T, ANTOLOVIĆ A 2012 Multicriteria Analysis of Fire Risk in the Split-Dalmatia County. Cartography and geoinformation 11 (17): 4-24

7. ROSAVEC R 2010 Relation between climate factors and the flammability of some Mediterranean species in forest fires. $\mathrm{PhD}$ thesis, University of Zagreb, Faculty of Forestry, Zagreb, Croatia, $175 \mathrm{p}$

8. MARTINOVIĆ J 2003 Management of forest soils in Croatia. Forest research institute Jastrebarsko and Croatian Forest Ltd., Jastrebarsko, Zagreb, Croatia, 521 p

9. FRANULOVIĆ K 2014 Protupožarne prometnice na kršu. Savjetodavna služba, URL: dostupno na: http:// www.savjetodavna.hr/savjeti/558/563/protupozarneprometnice-na-krsu/ (15 August 2017)

10. MALOY MA, DEAN DJ 2001 An accuracy assessment of various GIS-based viewshed delineation techniques. Photogramm Eng Rem S 67 (11): 1293-1298

11. VASILAKOS C, KALABOKIDIS K, HATZOPOULOS J, KALLOS G, MATSINOS Y 2007 Integrating new methods and tools in fire danger rating. Int J Wildland Fire 16 (3): 306-316. DOI: https://doi.org/10.1071/WF05091

12. PATAH NA, MANSOR S, MISPAN MR 2001 An application of remote sensing and geographic information system for forest fire risk mapping. Malaysian Centre for Remote Sensing (MACRES), pp 54-67
13. ROLAND V, MARIĆ I, MILOŠEVIĆ R 2015 Application of GIS technology in firefighting. Vatrogastvo $i$ upravljanje požarima (Fire fighting and management), 1 (5): 57-71 (in Croatian with English summary)

14. CHUVIECO E, SALAS J 1996 Mapping the spatial distribution of forest fire danger using GIS. Int J Geograph Inf Sci 10 (3): 333-345. DOI: https://doi.org/10.1080/02693799608902082

15. KARADIMAS N V, KOLOKATHI M, DEFTERAIOU G, LOUMOS V 2007 Ant colony system vs ArcGIS network analyst: The case of municipal solid waste collection. In: 5th WSEAS International Conference on Environment, Ecosystems and Development, Tenerife, Spain, pp 128-134

16. ODOBAŠIĆ D 2009 Specifikacija i implementacija mrežnih modela prostornih podataka. Diploma thesis, University of Zagreb, Faculty of Geodesy, Zagreb, Croatia, $82 \mathrm{p}$

17. DRAGIČEVIĆ JS 2007 Gospodarenje šumama u Hrvatskoj i na primorskom području. Građevinar 59: 447-453

18. ŠĆEPANOVIĆ J, BUČAN P, KOVAČEVIĆ । 2012 Analysis of intervention fire extinguishing "DES" Split. Vatrogastvo $i$ upravljanje požarima (Fire fighting and management) 2 (2): 67-80 (in Croatian with English summary)

19. AKAY AE, WING MG, SIVRIKAYA F, SAKAR D 2012 A GIS-based decision support system for determining the shortest and safest route to forest fires: a case study in Mediterranean Region of Turkey. Environ Monit Assess 184 (3): 1391-1407. DOI: https//doi.org/10.1007/s10661-011-2049-z

20. KERAMITSOGLOU I, KIRANOUDIS CT, SARIMVEIS H, SIFAKIS N 2004 A multidisciplinary decision support system for forest fire crisis management. Environ Manage 33 (2): 212-225. DOI: https://doi.org/10.1007/s00267-003-0092-4

21. GENDREAU M, LAPORTE G, SEMET F 2001 Adynamic model and parallel tabu search heuristic for real-time ambulance relocation. Parallel Comput 27 (12): 1641-1653. DOI: https:// doi.org/10.1016/S0167-8191(01)00103-X

22. GHIANI G, GUERRIERO F, LAPORTE G, MUSMANNO R 2003 Real-time vehicle routing: Solution concepts, algorithms and parallel computing strategies. Eur J Oper Res 151 (1): 1-11. DOI: https://doi.org/10.1016/S0377-2217(02)00915-3

23. DRŽAIĆ D, KAVRAN M, ANTOLOVIĆ A 2014 Determination of Appropriate Locations for Seasonal Dislocation of Fire Stations in the Šibenik-Knin County Based on Road Network Analysis. Cartography and geoinformation 22 (13): 20-31 